\title{
RSPO3 wt Allele
}

National Cancer Institute

\section{Source}

National Cancer Institute. RSPO3 wt Allele. NCI Thesaurus. Code C52307.

Human RSPO3 wild-type allele is located in the vicinity of $6 \mathrm{q} 22.33$ and is approximately 79 $\mathrm{kb}$ in length. This allele, which encodes R-spondin-3 protein, is involved in the regulation of the beta-catenin signaling pathway. 